\title{
Bioinsektisida Ekstrak Kulit Pisang Kepok (Musa paradisiaca) Terhadap Mortalitas Ulat Grayak (Spodoptera litura) pada Sawi Hijau (Brassica juncea L)
}

\author{
I.A.K Pramushinta \\ Staf pengajar Prodi Farmasi FSK Universitas PGRI Adi Buana \\ Email : iak.pramushinta@unipasby.ac.id
}

\begin{abstract}
ABSTRAK
Pengendalian hama dilakukan dengan bioinsektisida yang bertujuan untuk mematikan ulat grayak yang ada pada tanaman sawi hijau. Pembuatan bioinsektisida dengan menggunakan ekstrak kulit pisang kapok (Musa paradisiaca) terhadap kematian ulat grayak. Analisis penelitian ini menggunakan Rancangan Acak Lengkap (RAL) dengan 4 perlakuan (0\%, 5\%, 10\%, 15\%) pengulangan sebanyak 6 ulangan. Pemberian bioinsektisida pada ulat grayak selama perlakuan dan penyemprotan 4 kali seminggu pada tanaman sawi hijau selama 5 minggu. Data penelitian dianalisis menggunakan uji ANOVA dan uji DUNCAN. Hasil penelitian menunjukkan pemberian bioinsektisida ekstrak kulit pisang kepok berpengaruh nyata $(\mathrm{P}<0,05)$ terhadap angka kematian ulat grayak (F hitung 64,931> F tabel 3,10), pertumbuhan tanaman sawi hijau (jumlah daun) (F hitung 15,748> F tabel 3.10), dan produksi sawi hijau (bobot basah) (F hitung 9.298> F tabel 3.10). Hasil uji DUNCAN menunjukkan perlakuan P3 (15\%) berbeda nyata dibandingkan perlakuan lainnya.
\end{abstract}

Kata kunci : Bioinsektisida, ekstrak kulit pisang kapok, ulat grayak, sawi

\section{ABSTRACT}

Pest control is carried out with bioinsecticides which aim to kill armyworms in mustard greens. Making bioinsecticides using kapok banana peel extract (Musa paradisiaca) against armyworm mortality. The research analysis used a completely randomized design (CRD) with 4 treatments ( $0 \%$, $5 \%, 10 \%, 15 \%)$ repetitions of 6 replications. Giving bioinsecticide to armyworms during treatment and spraying 4 times a week on mustard greens for 5 weeks. The research data were analyzed using the ANOVA test and the DUNCAN test. The results showed that the application of Kepok banana peel extract bioinsecticide had a significant effect $(\mathrm{P}<0.05)$ on armyworm mortality ( $\mathrm{F}$ count $64.931>\mathrm{F}$ table 3.10), green mustard plant growth (number of leaves) ( $F$ count 15.748> F table 3.10), and green mustard production (wet weight) (F count 9,298> F table 3.10). The results of the DUNCAN test showed that P3 treatment (15\%) was significantly different than other treatments.

Keywords: Bioinsecticide, Kepok banana peel extract, armyworm, green mustard.

\section{PENDAHULUAN}

Tanaman sawi hijau merupakan sayuran yang banyak diminati oleh masyarakat terutama petani, karena tanaman sawi termasuk sayuran yang bisa ditanam diberbagai musim. Apabila ditanam pada hawa yang sejuk maka pertumbuhan tanaman sawi akan lebih cepat tumbuh karena dalam keadaan yang lembab (Nurshanti, 2010).
Pada tahun 2012 produksi tanaman sawi mengalami penurunan sekitar 26,6\%. Penurunan produksi tersebut terjadi karena akibat serangan hama. Hama yang sering menyerang dan merugikan tanaman pangan tersebut adalah hama ulat grayak (Spodoptera litura) (Sa'diyah et al., 2013). Apabila permasalahan tersebut tidak segera dicegah,maka daun sawi hijau akan habis dimakan larva. (Wahyu dan Indah, 2016). 
Salah satu cara untuk membasmi organisme pengganggu tanaman (OPT) yaitu dengan menggunakanbioinsektisida. Salah satu tanaman yang bisa digunakan sebagai bioinsektisida adalah tanaman pisang kepok, karena kulit pisang kepok (Musa paradisiaca) mempunyai kandungan bahan aktif seperti flavonoid, tannin, alkaloid, dan saponin (Lumowa \& Bardin, 2018).

Tujuan dari penelitian ini yaitu untuk mengetahui pengaruh bioinsektisida ekstrak kulit pisang kepok (Musa paradisiaca) terhadap mortalitas ulat grayak (Spodoptera litura) dan biomassa tanaman sawi hijau (Brassica juncea L.)

\section{METODE PENELITIAN}

Penelitian dilakasanakan di Laboratorium Biologi Dasar, Fakultas Sains Teknologi Universitas PGRI Adi Buana Surabaya.

Penelitian ini dilakukan dengan menggunakan metode Rancangan Acak Lengkap (RAL) yang perlakuannya terdiri dari 4 perlakuan dan 6 kali ulangan dengan konsentrasi $0 \%, 5 \%, 10 \%$, dan $15 \%$.

\section{Pembuatan Ekstrak Kulit Pisang Kepok}

Kulit pisang kepok hijau yang sudah disortir dipotong kecil-kecil dan dikeringkan dalam suhu ruangan selama 4-5 hari, kemudian dijadikan serbuk. Setelah itu dimaserasi dengan alkohol $96 \%$ dengan perbandingan 1:4 selama 3 hari. Kemudian di destilasi dan dilanjut pengovenan dengan suhu $70^{\circ}-\mathrm{C}-80^{\circ} \mathrm{C}$. Hasil yang diperoleh tersebut disimpan dalam wadah tertutup.

\section{Aplikasi Bioinsektisida Kulit Pisang Kepok terhadap Mortalitas Ulat grayak (Spodoptera litura)}

Ulat grayak yang sudah diperoleh kemudian dimasukkan dalam wadah dan setiap wadah diisi ulat grayak sebanyak 10 ekor, dan disemprotkan bioinsektisida ekstrak kulit pisang kepok setiap perlakuan sebanyak $1 \mathrm{ml}$.

\section{Parameter Pengamatan}

Penghitungan mortalitas dilakukan setelah 24 jam. Ulat grayak yang mati merupakan yang tidak bergerak atau tidak merespon terhadap rangsangan.

\section{Persiapan Media Semai dan Penyemaian Biji Sawi}

Media semai yang akan digunakan adalah tanah, taburkan atau semaikan tanaman sawi hijau selama 2 minggu hingga tanaman tumbuh 3-4 daun sejati pada polybag kecil berukuran $15 \times 15 \mathrm{~cm}$ yang sudah disiapkan.

\section{Persiapan Media Tanam}

Media tanam disiapkan satu minggu sebelum bibit sawi hijau ditanam. Media tanam yang digunakan tanah : pupuk kandang : arang sekam dengan perbandingan $2: 1: 1$

\section{Penanaman dan Pemeliharaan Tanaman Sawi Hijau \\ Bibit tanaman sawi hijau yang sudah} berumur 2 minggu dipindah pada polybag yang telah disiapkan, setiap polybag berisi 1 tanaman, dan penyiraman dilakukan 2 kali sehari setiap pagi (09.00) dan sore (16.00) dengan volume $100 \mathrm{ml}$ tiap penyiraman.

\section{Parameter Pengamatan}

Jumlah daun tanaman (helai), dan berat basah tanaman $(\mathrm{g})$.

\section{Penyemprotan Bioin sektisida Pada Tanaman Sawi Hijau \\ Penyemprotan dimulai saat tanaman} berumur 2 minggu dari penyemaian. Penyemprotan dilakukan secara teratur setiap 1 minggu sekali pada pukul 15.00-17.00 WIB dengan volume 1 kali semprot, yaitu $9 \mathrm{~m} / 100 \mathrm{ml}$ dengan ketentuan $3 \mathrm{ml}$ dari atas tanaman sawi $3 \mathrm{ml}$ dari samping kanan tanaman sawi $3 \mathrm{ml}$ dari samping kiri tanaman sawi.

\section{Analisis Data}

Hasil penelitian dihitung menggunakan SPSSdengan metode analisis uji F (ANOVA). Apabila hasil uji ANOVA berbeda nyata maka dilakukan uji lanjut menggunakan uji DUNCAN.

\section{HASIL DAN PEMBAHASAN}

Analisis mortalitas ulat grayak

Hasil penelitian menunjukkan bahwa pemberian bioinsektisida ekstrak kulit pisang kepok (Musa paradisiaca) dengan perlakuan yang berbeda terdapat pengaruh yang signifikan $(\mathrm{P}<0,05)$ pada mortalitas ulat grayak 
(S.litura F.). Hasil uji ANOVA mortalitas ulat grayak dapat dilihat pada Tabel 1.

Tabel 1. ANOVA Mortalitas Ulat Grayak

ANOVA

Mortalitas
\begin{tabular}{|c|c|c|c|c|c|}
\hline & $\begin{array}{c}\text { Sum of } \\
\text { Square } \\
\text { s }\end{array}$ & Df & $\begin{array}{c}\text { Mean } \\
\text { Square }\end{array}$ & F & Sig \\
\hline Between & 157,45 & 3 & 52,486 & 64 &, 00 \\
Groups & 8 & & & 31 & 0 \\
\hline Within & 16,167 & 20 &, 808 & & \\
Groups & & & & & \\
\hline Total & $\begin{array}{c}173,62 \\
5\end{array}$ & 23 & & & \\
& & & & \\
\hline
\end{tabular}

Rata-rata mortalitas ulat grayak pada konsentrasi $15 \%$ merupakan konsentrasi yang paling optimum dikarenakan penyemprotan larutan bioinsektisida yang sangat pekat. Diagram rata-rata mortalitas ulat grayak dapat dilihat pada Gambar 1.

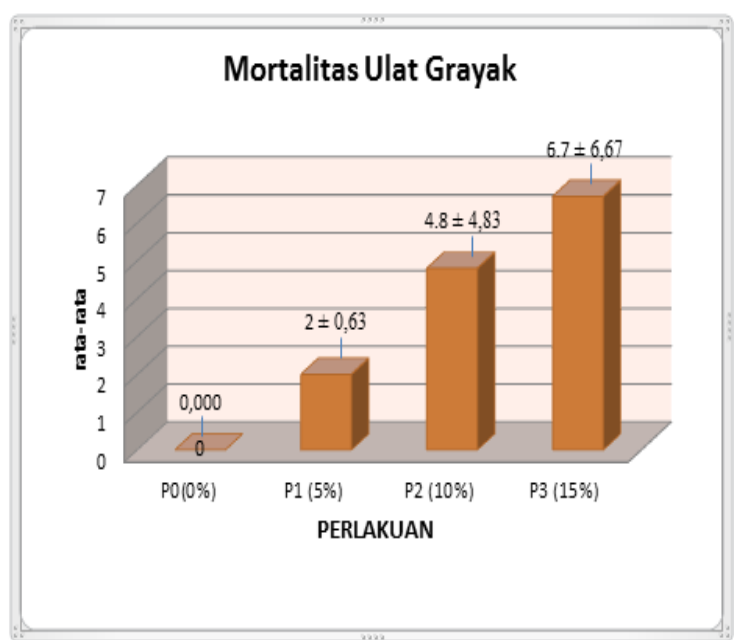

Gambar 1. Diagram Rata-Rata Mortalitas Ulat Grayak (Spodoptera litura)

\section{Analisis Jumlah Daun Tanaman Sawi Hijau}

Pemberian bioinsektisida ekstrak kulit pisang kapok menggunakan perlakuan berbeda sehingga terdapat pengaruh yng signifikan $(\mathrm{P}<0,05)$ pada jumlah daun sawi hijau. Hasil ANOVA pada jumlah daun sawi hijau dapat dilihat pada Tabel 2.
Tabel 2. ANOVA Jumlah Daun Sawi Hijau

\section{ANOVA}

Jumlah_Daun
\begin{tabular}{|c|c|c|c|c|c|}
\hline & $\begin{array}{c}\text { Sum of } \\
\text { Square } \\
\text { s }\end{array}$ & $\begin{array}{c}\text { D } \\
\mathrm{f}\end{array}$ & $\begin{array}{c}\text { Mean } \\
\text { Squar } \\
\text { e }\end{array}$ & F & Sig \\
\hline $\begin{array}{c}\text { Betwee } \\
\mathrm{n} \\
\text { Groups }\end{array}$ & 42,125 & 3 & 14,042 & $\begin{array}{c}15,74 \\
8\end{array}$ & $\begin{array}{c}, 00 \\
0\end{array}$ \\
\hline $\begin{array}{c}\text { Within } \\
\text { Groups }\end{array}$ & 17,833 & 20 &, 892 & & \\
\hline Total & 59,958 & 23 & & & \\
\hline
\end{tabular}

Rata-rata jumlah daun (gambar 2) menunjukkan bahwa konsentrasi $0 \%$ paling rendah dan konsentrasi $15 \%$ paling tinggi, dikarenakan penyemprotan larutan bioinsektisida yang sangat pekat. Jumlah daun sawi hijau dapat dilihat pada Gambar 2.

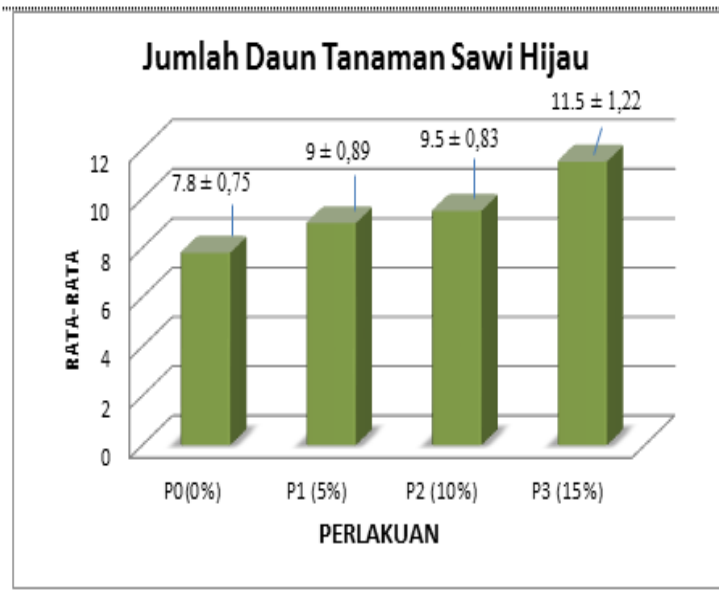

Gambar 2. Diagram Rata-Rata Jumlah Daun Sawi Hijau

\section{Analisis Berat Basah Tanaman Sawi Hijau}

Hasil penelitian menunjukkan bahwa pemberian bioinsektisida ekstrak kulit pisang kepok(Musa paradisiaca) dengan perlakuan yang berbeda terdapat pengaruh yang signifikan $(\mathrm{P}<0,05)$ pada berat basah sawi hijau. Hasil ANOVA berat basah sawi hijau dapat dilihat pada Tabel 3. 
Tabel 3. ANOVA Berat Basah Sawi Hijau

Berat_Basah
\begin{tabular}{|c|c|c|c|c|c|}
\hline & Sum of & D & Mean & F & Sig \\
& Squares & f & Square & & \\
\hline $\begin{array}{c}\text { Betwee } \\
\mathrm{n}\end{array}$ & 379,125 & 3 & 126,37 & 9,29 &, 00 \\
Groups & & & 5 & 8 & 0 \\
\hline Within & 1271,83 & 20 & 13,592 & & \\
Groups & 3 & & & & \\
\hline Total & 650,958 & 23 & & & \\
\hline
\end{tabular}

Berdasarkan Gambar 3 menunjukkan bahwa konsentrasi 0\% paling rendah dan konsentrasi $15 \%$ paling tinggi, dikarenakan penyemprotan larutan bioinsektisida yang sangat pekat. Diagram rata-rata berat basah sawi hijau dapat dilihat pada Gambar 3.

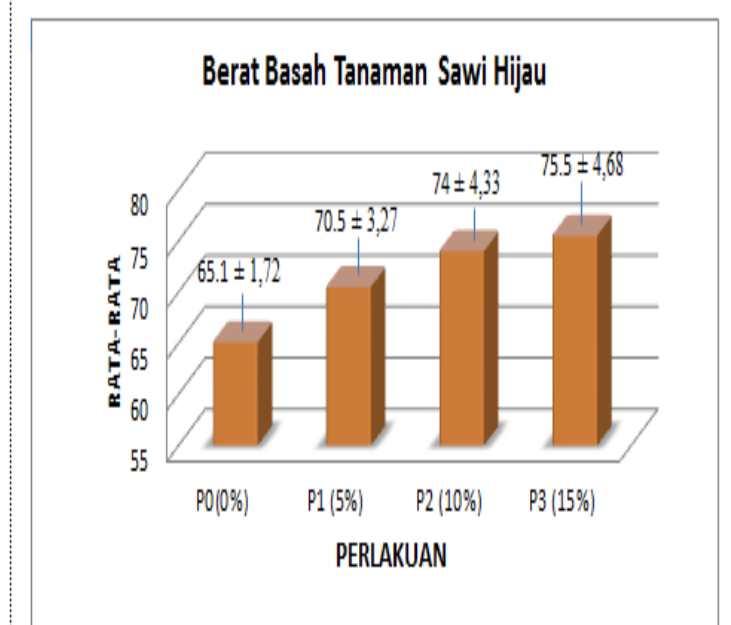

Gambar 3. Diagram Rata-Rata Berat Basah Sawi Hijau

\section{Pembahasan}

Mortalitas Ulat Grayak (Spodoptera litura)

Analisis data mortalitas ulat grayak diperoleh $\mathrm{F}$ hitung 64,931 dan $\mathrm{F}$ tabel 3,10 dengan taraf signifikan. Dari hasil tersebut maka Fhitung>Ftabel, sehingga berarti ada pengaruh nyata terhadap perlakuan yang telah diberikan. Penjelasan tersebut juga didukung oleh analisis data SPSS yang memberikan hasil yang signifikan $(\mathrm{P}<0,05)$. Uji DUNCAN diketahui bahwa berbeda nyata setiap perlakuannya.
Pada penelitian ini, bioinsektisida dengan konsentrasi $15 \%$ memiliki konsensentrasi tertinggi dari perlakuan lainnya, sehingga hasilnya dapat memberikan efek kematian yang optimum pada ulat grayak. Berdasarkan penelitian Purba (2007) megatakan bahwa konsentrasi berbanding lurus dengan bahan racun, sehingga daya bunuh semakin tinggi.

Pada hasil pengamatan 24 jam, pada konsentrasi $0 \%$ tidak ditemukan adanya larva ulat grayak yang mati, sedangkan pada konsentrasi $5 \%$, 10\%, dan $15 \%$ ditemukan adanya larva ulat grayak yang mati, hama ulat grayak yang mati dengan pemberian bioinsektisida ekstrak kulit pisang kepok mengalami pengerutan pada tubuh ulat grayak, serta ada yang masih hidup namunhama bergerak sangat lambat dan apabila disentuh selalu menggulungkan tubuhnya akibat senyawa aktif bioinsektisida. Ulat grayak yang masih hidup, namun hama bergerak sangat lambat dengan menggulungkan tubuhnya serta gerakan tubuh ulat grayak dan tubuhnya mengalami pengerutan dapat dilihat pada Gambar 4 dan Gambar 5.

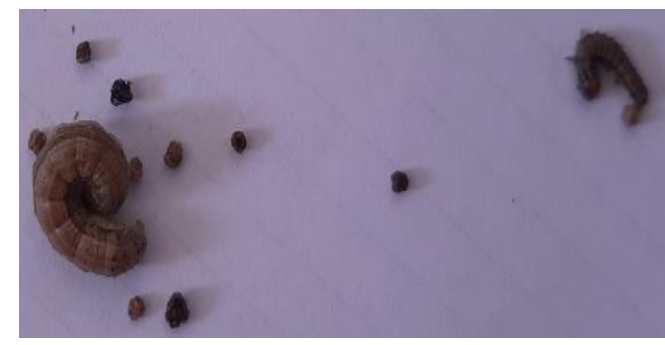

Gambar 4. Ulat grayak masih hidup,namun hama bergerak sangat lambat dan menggulungkan tubuhnya

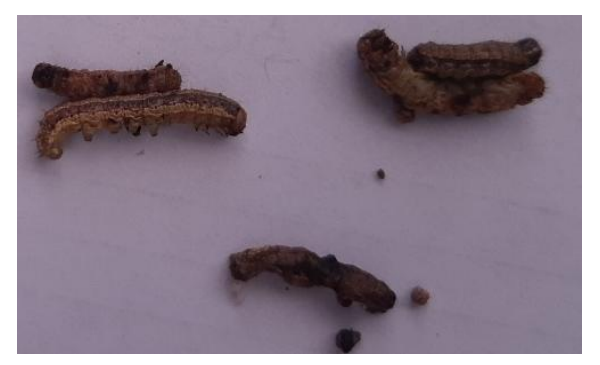

Gambar 5. Menunjukkan tidak adanya gerakan tubuh ulat grayak dan tubuhnya mengalami pengerutan. 
Hal ini diduga bahwa kematian ulat grayak disebabkan karenakelumpuhan pada sel syaraf dan otot, terjadi karena kandungan senyawa aktif yang ada pada ekstrak bioinsektisida kulit pisang kepok masuk ke dalam tubuh larva melalui mekanisme racun kontak dan saluran pernapasan sehingga larva cenderung tidak bergerak (lemah). Ekstrak kulit pisang kepok mempunyai kandungan fitokimia yang dapat memberi pengaruh terhadap serangga. Bahan aktif dari kulit pisang kepok yaitu saponin, tanin, flavonoid, dan alakaloid (Lumowa dan Bardin, 2018).

Saponin merupakan racun perut bagi larva. Tegangan permukaan selaput mukosa traktus digestivus larva dapat menurun karena senyawa aktif saponin tersebut sehingga dinding traktus digestivus menjadi korosif. Apabila senyawa tersebut masuk kedalam tubuh larva maka alat pencernaan larva akan terganggu (Wardani et al., 2010). Tanin tidak dapat mengganggu serangga dalam mencerna makanan, namun proses pada pencernaan larva dapat terganggu akibat tannin, karena tanin akan mengikat protein dalam sistem pencernaan yang diperlukan serangga untuk pertumbuhan.

Menurut Cahyadi (2009) senyawa alkaloid dan flavonoid dapat bertindak sebagai stomach poisoning atau racun perut. Oleh karenaitu, apabila kedua senyawa tersebut masuk ke dalam tubuh larva maka alat pencernaannya akan terganggu.

\section{Jumlah Daun Sawi Hijau}

Pada hasil akhir analisis data mortalitas ulat grayak diperoleh $\mathrm{F}$ hitung 15,748 dan $F$ tabel 3,10 dengan taraf signifikan. Dari hasil tersebut maka Fhitung $>$ Ftabel, sehingga berarti ada pengaruh nyata terhadap perlakuan yang telah diberikan. Penjelasan tersebut juga didukung oleh analisis data dengan bantuan program SPSS yang memberikan hasil yang signifikan $(\mathrm{P}<0,05)$. Pada hasil uji DUNCAN diketahui bahwa antar perlakuan berbeda nyata kecuali pada perlakuan $5 \%$ dengan $10 \%$ tidak berbeda nyata.

Pada perlakuan P0 (0\%) tanaman sawi hijau tidak diaplikasikan bioinsektisida hanya disemprot dengan aquades sehingga tanaman sawi hijau banyak yang terserang hama ulat grayak karena larva dapat berkembang dengan baik. Daun sawi hijau mengalami kerusakan parah banyak yang berlubang, dan daun tidak beraturan. Sehingga jumlah daun mengalami penurunan. Hal ini sesuai dengan penelitian Azwana dan Adikorelsi (2009) bahwa tanaman diserang hama ulat grayak pada stadia larva. Daun menjadi berlubang dan bentuknya tidak beraturan karena larva banyak menyerang pada bagian daunnya.

Pada perlakuan P3 (15\%) ekstrak kulit pisang kepok dengan konsentrasi tersebut menghasilkan rata-rata jumlah daun tanaman sawi hijau tertinggi dari perlakuan lainnya, karena semakin besar kandungan bioinsektisida ekstrak kulit pisang kepok yang diberikan maka semakin tinggi residu senyawa aktif yang ditinggalkan. Sehingga larva ulat grayak berkurang karena tidak dapat berkembang dengan baik. Kerusakan daunnya juga berkurang, maka jumlah daun mengalami peningkatan.

Metamorfosis hama yang memiliki metamorfosis sempurna dapat digagalkan oleh ekstrak kulit pisang kepok, hama yang menyerang tanaman sawi hanya dapat berkembang sampai pada tahap perkembangan larva saja. Proses larva menjadi pupa terhambat karena senyawa alkaloid, senyawa tersebut merupakan toksik yang merusak jaringan saraf. (Wiratno, 2010).

Hasil analisis membuktikan bahwa kandungan ekstrak kulit pisang kapok mempengaruhi jumlah daun sawi hijau sehingga dapat melindungi daun dari serangan hama ulat grayak yang berdampak pada meningkatnya jumlah daun

\section{Berat Basah Tanaman Sawi Hijau}

Pada hasil akhir analisis data mortalitas ulat grayak diperoleh F hitung 9,298 dan $\mathrm{F}$ tabel 3,10 dengan taraf signifikan. Dari hasil tersebut maka Fhitung $>$ Ftabel, sehingga berarti ada pengaruh nyata terhadap perlakuan yang telah diberikan. Penjelasan tersebut juga didukung oleh analisis data dengan bantuan program SPSS yang memberikan hasil yang signifikan $(\mathrm{P}<0,05)$. Uji DUNCAN diketahui bahwa konsentrasi 5\% dengan $10 \%$ tidak berbeda nyata dan konsentrasi $10 \%$ juga tidak berbeda nyata dengan $15 \%$. 
Dari hasil penelitian yang sudah dilakukan, pada perlakuan P0 $(0 \%)$ tanaman tidak memperoleh senyawa aktif dari ekstrak kulit pisang kepok, sehingga daun sawi mengalami intensitas serangan hama ulat grayak yang sangat buruk, sehingga hasil produksi berat basah sawi hijau mengalami penurunan. Hal ini sesuai dengan penelitian Julaily,et al (2013), bahwa banyaknya jumlah daun tanaman sawi yang diserang oleh hama berpengaruh pada besar kecilnya berat basah tanaman sawi hijau. Semakin tinggi tingkat kerusakan maka berat basah juga semakin rendah.

Pada perlakuan P3 (15\%) memperoleh senyawa aktif dari ekstrak kulit pisang kepok dan mengandung tingkat kepekatan ekstrak kulit pisang kepok yang sangat tinggi, sehingga hasil produksi berat basah mendapatkan hasil yang paling optimum dari perlakuan lainnya. Hal ini sesuai dengan penelitian Sucipto (2011) bahwa penggunaan bioinsektisida dapat meningkatkan produksi tanaman sawi. Jika tingkat kerusakannya rendah maka berat basahnya akan semakin tinggi.

Ekstrak kulit pisang kepok mengandung flavonoid. Kandungan flavonoid mempunyai sifat insektisida serta menimbulkan Pelemahan organ saraf (pernafasan) yang dapat mengakibatkan kematian terjadi karena flavonoid menyerang beberapa organ saraf dan organ vital serangga, (Dinata, 2009). Flavonoid bekerja sebagai inhibitor pernafasan. Zat yang menghambat atau menurunkan laju reaksi kimia merupakan inhibitor, flavonoid juga dapat menghambat sistem pengangkutan elektronsehingga mengganggu mekanisme energi didalam mitokondria. (Agnetha, 2008).

Dari hasil penelitian telah membuktikan bahwa kandungan ektrsak kulit pisang kepok dapat mempengaruhi berat basah produksi tanaman sawi hijau karena dapat membrantas hama yang berdampak pada meningkatnya jumlah daun dan jumlah produktifitas tanaman sawi hijau (Brassica juncea).

\section{KESIMPULAN}

Kesimpulan dari penelitian ini yaitupenelitian pemberian bioinsektisida ekstrak kulit pisang kepok (Musa paradisiaca) berpengaruh signifikan terhadap jumlah mortalitas hama ulat grayak (Spodoptera litura). Konsentrasi optimum mortalitas ulat grayak pada perlakuan P3 (15\%) dibandingkan dengan perlakuan yang lainnya. Pada jumlah daun dan berat basah juga menunjukkan adanya pengaruh signifikan pada ekstrak kulit pisang kepok.

Diharapkan bagi masyarakat khususnya para petani, bisa menggunakan bioinsektisida ekstrak kulit pisang kepok untuk membasmi hama dan meningkatkan jumlah daun tanaman sawi hijau, karena aman digunakan dan tidak menyebabkan resistensi hama akibat terlalu banyak penggunaan insektisida kimia, untuk pemberian bioinsektisida ekstrak kulit pisang kepok paling optimum pada konsentrasi $15 \%$. Sedangkan bagi peneliti, dapat mengembangkan penelitian uji lanjut dengan konsentrasi yang lebih tinggi lagi, dan juga bisa menggunakan hama yang lain seperti hama ulat Plutellaxylostella.

\section{REFERENSI}

Adriyana, M 2014. Kemempanan insektisida nabati mikrobia dan kimia sintetis terhadap ulat Plutella xylostella. Hlm. 86-90 Dalam Prosiding Hasil Penelitian dalam rangka Pemanfaatan Pestisida Nabati. D. Soetopo (editor). Bogor.

Azwana dan Adikorelsi T. 2009. Preferensi Spodoptera lituraF. Terhadap Beberapa Pakan. Jurnal Pertanian dan BiologiUniversitas Medan Area. 1(1):29-30

Chaieb I. (2010). Saponin as insectide : a review. Tunisian. J. Of Plant Protection. Vol. 5:39-50.

Julaily, N., Mukarlina, \& Setyawati, T. R. (2013). Pengendalian Hama pada Tanaman Sawi (Brassica juncea L.) Menggunakan Ekstrak Daun Pepaya (Carica papaya L.). Jurnal Protobiont, Vol 2 (3): 171-175.

Lumowa, S. V., \& Bardin, S. (2018). Uji Fitokimia Kulit Pisang Kepok (Musa paradisiaca) Bahan Alam Sebagai Pestisida Nabati Berpotensi Menekan Serangan Serangga Hama Tanaman Umur Pendek.Jurnal Sains dan Kesehatan, Vol 1. N0.9. 
Nurshanti, $\quad$ D.F.2010.

PengaruhPemberianPupukOrganikTerh adapPertumbuhandanHasilTanamanSa wiCaisim (Brassica juncea L.).JurnalAgrotebisnis. Vol 1: No. 1

Sa'diyah, N.A., Purwani, K.I., danWijayawat, L. 2013. PengaruhEkstrakDaunBintaro (Cerberaodollam) terhadapPerkembanganUlatGrayak (Spodopteralitura).JurnalSainsdanSeniP omits, 2 (2).

Sartono \& Sumarmi, 2007, Kajian Insektisida Hayati terhadap Daya Bunuh Ulat Plutella xylostella dan Crocidolomia binotalis pada Tanaman Kubis Krop. Fakultas Pertanian.

Wahyu, B. dan Indah, K. 2016.PengaruhEkstrakDaunBelimbingW uluh (Averrhoabilimbi) TerhadapMortalitasdanPerkembangan Larva Spodopteralitura.JurnalSainsdanSeni ITS, 5 (2): 2337-3520.

Wardani, R., S., Mifbakhuddin, Kiki, Y. (2010). Pengaruh Konsentrasi Ekstrak Daun Tembelekan (Lantara camara) Terhadap kematian Larva Aedes aegypti. Vol 6:2.

Wiratno, 2010. Bebeapa Formula Pestisida Nabati dari Cengkeh, Journal Agritek, vol. 13, no. 1, hal. 6-12.

Yunita,E., Suprapti, N., Hidayat, J. 2009. Pengaruh Ekstrak Daun Teklan (Eupatoriumriparium) terhadap Mortalitas dan Perkembangan larva Aedes aegepti. Bioma, Juni 2009. Vol. 11, Hal 11-17 ISSN: 1410-8801 